DOI: https://doi.org/10.47264/idea.lassij/4.1.26

Vol. 4, No. 1, (January-June 2020): 303-316

Research Article

URL: https://www.ideapublishers.org/index.php/lassij

\title{
Counter-Terrorism: Push and Pull Factors Impacting Male Youth Involved in Violent Extremism in Punjab, Pakistan
}

\author{
Tehmina Aslam*1, S. M. Ali Shah Rizvi² \& Muhammad Asad Aslam ${ }^{3}$ \\ 1. School of Integrated Social Sciences, The University of Lahore, Lahore, Pakistan. \\ 2. Research Society of International Law (RSIL), Lahore Office, Lahore, Pakistan. \\ 3. Faculty of Law, The University of Lahore, Lahore, Pakistan.
}

Received: February 3, 2020

Published: December 12, 2020

\begin{abstract}
The study examines contribution of societal dogmas and extremist religious ideologies pushing the youth to religious extremism. It asses contribution of people's persuasion and the state's coercive measures ranging from law enforcement to physical actions to pull the youth return to peace. The study is qualitative for which interviews are conducted with former militants, their relatives, and friends in Sargodha and Jhang, Pakistan. Four main findings are: First, societal dogmas to devote one's life for a religious cause motivated the youth to resort to extremism. Second, extremist religious ideologies centred upon jihadism to sacrifice one's life for a religious cause pushed the youth to terrorism. Third, people's persuasion especially persuasion by families acted as a major pull factor to bringing the youth back to normal life. Fourth, the state's coercive hand in enforcement of law and order, security operations, jails and other police actions dissuaded the youth to tread further the path of terrorism. Nonetheless, the pull factors such as societal dogmas and religious ideologies played their role in motivating the youth to terrorism. The pull factors such as people's persuasion and the state's coercion outclassed them to assert peace thus preventing them from falling into the abyss of terrorism.
\end{abstract}

Keywords: Extremism, Violent Extremism, Countering Extremism, Youth, Radicalisation, Youth Radicalisation, Counter-Terrorism, Counter-Terrorism Strategy.

\section{Introduction}

The youth sometimes oscillate between terrorism and peace. The instigating factors open space for the youth to get involved in terrorist activities, but advice and punitive laws and actions taken by the state pull them back to normalcy and peace. This leads to the degeneration of society in general and the country as a whole. The instigating factors open space for the youth to get involved in terrorist activities, but advice and punitive laws and actions taken by the State pull them back to normalcy and peace.

The post-1979 age, in the wake of the invasion of Afghanistan by the forces of the Union of Soviet Socialist Republics (USSR), transformed Pakistan's society in many ways. One of them was the tendency in the youth to yearn for militancy (Phillips, 2016). Though post-1989 the forces of the USSR withdrew, Pakistan remained in the grip of militancy. Weapons and ideology started travelling from Afghanistan to Pakistan polluting first the border areas and then the heartland of Pakistan (Haqqani, 2013; Khan et al., 2019). The conflict which was 
foreign turned local. Both weapons and militant ideology started influencing Pakistani society (MacDonald, 2017; Wasai et al., 2020). Sectarian fault lines, which had remained submerged, started appearing. Post-9/11 again created an environment in Afghanistan seemed to be attractive to the weapon lovers and ideology driven Pakistanis, especially the youth (Rogers, 2017; Khan et al., 2020). Be it now the Jihad (holy war) concept or the sectarian disharmony, Pakistan has lost precious lives of both civilians and the security forces (MacDonald, 2017). The youth have been the worse hit, for in their tender age, it is difficult to decide for them to toe the correct line and when they pass the line, it is sometimes difficult for them to get back to the normal life.

With rising cases of extremism prevalent in Pakistan over the past two decades, it was prudent to create a study where one could examine the factors pushing the youth towards these ideologies. The aim of the study was to examine the contribution of societal dogmas and extremist religious ideologies to pushing the youth to religious extremism. Furthermore, the study examines the contribution of people's persuasion and the State's coercive measures ranging from law enforcement to physical actions to pull the youth return to peace. The article begins by explaining the relevant literature published on this topic, moving on to discussions of various push and pull factors with accounts from rehabilitated extremists and their viewpoints. Lastly, the conclusions drawn from the findings are stated along with various recommendations that one should follow.

\section{Literature Review}

After 1989, Pakistan witnessed an upsurge in extremist religious organisations dividing society along sectarian lines (Ahmed, 2012). One such organization was the Sipahe Sahaba Pakistan (SSP), a sectarian Sunni organization founded by Maulana Haq Nawaz Jhangvi and his companions (who were followers of the Deoband school of thought) on 6 September 1985 in Jhang, Punjab with the declared objective of countering the Shia influence and making effort to declare Pakistan a Sunni state (Cohen, 2016). The SSP used to run about 17,000 religious seminaries (Sunni sect) across the country and did social work to woo voters to elect their representatives in elections (Cohen, 2016). The organization was popular in South Punjab, rural Sindh and Khyber Pakhtunkhwa, and it remained closely associated with the Tehreke Taliban Pakistan (TTP) and al-Qaeda (Haqqani, 2013).

After 1989, two deadly Jihad (holy war) promoting organizations reared their heads in Pakistan. One was the Lashkar-e-Taiba (LeT) and the second was the Jaish-e-Mohammd (JeM). The LeT was founded in 1987 by Hafiz Saeed and his companions in Afghanistan (Cohen, 2016). They made the headquarters in Mureedke, near Lahore, but it was functional in Azad Kashmir associated with Pakistan by running training camps there (MacDonald, 2016). The LeT was accused of inflicting the Mumbai attacks on mainland India on 7 December 2008 (Woodward, 2011). The United Nations (UN) banned it under its Resolution 1267, which was an al-Qaeda Sanctions list (Khan, 2018). On 12 January 2002, President General Pervaiz Musharraf regime also banned the LeT (Cohen, 2016). Afterwards, the LeT re-emerged in the shape of the Jamat-ud Dawah (JuD). After the Mumbai attacks in 2008, the JuD was also banned in Pakistan. In December 2008, Hafiz Saeed was declared international terrorist under the UNSC Resolution 1267. In June 2014, the US also declared the JuD a terrorist organization. After the Pulwama attack on $14^{\text {th }}$ February 2019, the Government of Pakistan banned the JuD on 20 ${ }^{\text {th }}$ February 2019 (Yousaf, 2019; Aslam \& Aslam, 2020). 
The JeM was founded by Maulana Masood Azhar in 2000 and this organization also remained associated with the Deoband school of thought (Cohen, 2016). The organization is based in Pakistan and it is said to have been active in Indian-held Kashmir (Cohen, 2016). The JeM has a branch in Indian-held Kashmir which claimed the responsibility for attacks on the Jammu and Kashmir Legislative Assembly in Srinagar in 1 October 2001 and on the Indian Parliament on 13 December 2001 (Cohen, 2016). The JeM also kept close links with other like-minded Deoband-thought inspired militant organizations such as the Tehreke Taliban Pakistan and alQaeda functional in Afghanistan (Woodward, 2011).

On 12 January 2002, under international pressure, President General Pervaiz Musharraf banned the JeM. However, members of the JeM remained scot-free and founded other organizations to continue their activities. In March 2016, India asked the 1267 committee to include the name of the JeM chief Maulana Masood Azhar on the list to declare him an international terrorist, as the JeM was listed as a banned organization in 2002 but not its chief, Masood Azhar (MacDonald, 2016). After the Pathankot attack, Maulana Masood Azhar was arrested but, in April 2016, he was released by Pakistan. In May 2019, UNSC listed Maulana Masood Azhar as a global terrorist (United Nations Security Council, 2019).

Various studies have been conducted to ascertain why the youth is being radicalized. A study focused on 131 Dutch Muslims showed that things such as group threats, uncertainty and injustices were what pushed the youth towards radicalization (Doosje et al., 2013). However, Pakistan does not necessarily fall under the umbrella of the results of this study because this was conducted in an area where Muslims were a minority whereas those radicalized in Pakistan are primarily from the majority Sunni sect.

In 2017, 2709 university students from Arab countries were taken as a sample by El-Badayneh and El-Hasan. Factors pushing towards radicalization were mostly Personal Factors, Family Factors and Societal Factors. This study is more relevant to Pakistani culture and mindset as it was conducted in a state where Muslims are in majority. However, it narrows itself into a niche as it only views university students in its sample size. Pakistan, according to World Education Services, is a country where only $6 \%$ of the population receives education beyond high school. Other factors differentiating Pakistan from these countries such as socio-economic factors, creates a need to do a focused study on Pakistani youth.

The research by Chebotareva (2014) shows how ethnic factors also pushed youth towards extremism (2014). The sample of 420 people was taken from six regions, namely, Russia, China, South America, Africa, Middle East and Central Asia. Multiple tests such as the Kruskall Wallis tests were used. The research showed that those who were more bigoted in terms of ethnicity were less tolerant of individuality or other social or ethnic groups. This study narrows down the key prevalent issues that push the youth towards extremism in Pakistan and its surrounding countries.

A 2019 study conducted on Malaysian Muslim youth utilized the expert interview approach. Inductive thematic analysis was used to analyze the data collected (Yusof et al., 2019). The main factors for youth inclination toward extremism were Islamic ideology and its interpretation, charismatic leadership and ummah and its practicality. The study was viewed from a socio ecological theory perspective and is relevant to Pakistan because both countries are Muslim majority areas. 
A Pakistan specific study by Ismail, Shah and Saleem stated that students gravitated towards extremism because of attraction to martyrdom, lack of basic rights, reaction to globalization/Americanization, media propaganda, religious ideology and societal pushes and mindsets (Ismail et al., 2020). The study focused on higher education students of Pakistan and examined how extremis was becoming more prevalent in youth mindset by utilizing probability-sampling technique with the survey method.

\section{Research Methodology}

A qualitative case study method based on key informant interviews was conducted of deradicalized former militants who were affiliated to militant organizations such as Sipahe Sahaba Pakistan, Lashkare Jhangvi, Laskhare Taibah and Jaishe Mohammad, all banned outfits in the country. They resided in Sargodha and Jhang, cities of the Punjab, Pakistan. Interviews of their siblings, parents and friends were also taken to understand the contribution of the identified push and pull factors.

Interviews were taken of the key individuals along with their family members in the exploratory research using qualitative methodology to discover why the youth were being pushed towards extremism and what factors pulled them back to safety. It was necessary to conduct interviews with these people because it led to a clear account of events that took place rather than second hand version of what pushed these people towards radicalization. The sample size is justifiably small because not many reformed extremists are incorporated back into society. Even less are those who are willing to provide interviews and expose themselves and their families in such a manner.

The interviews were from Anwar Ali (Sipah-e-Sihaba), whose mother stated that it was peer pressure that turned her son towards sectarian hatred and extremism. Asif Hussain, another former extremist agreed with this push factor and also cited the various social and religious factors pushing youngsters towards an extremist mindset. Umar Muavia and his brother Aslam Muavia also put the blame on society's doorstep with friends playing a huge role towards pushing the youth towards deviance. All the names given in this research are pseudonyms provided the nature of the research and the sensitivity of the topic.

All these individuals believed that religious devotion or, in this case, extremist religious ideologies became a huge push factor for people to turn towards extremism. In terms of pull factors, in almost all cases, family and familial affiliation pulled these former extremists back and incorporated them into society once again. Most of the families were under threat by the police and it provoked the extremists to come out of hiding and give themselves up. Furthermore, coercion and the rehabilitation efforts by the state provided these former extremists with understanding of what religion truly meant and how to utilize their energies in a positive manner, training them for useful employments.

\section{Discussion and Findings}

Terrorism is not an act that automatically takes root in society. The underlying factors make the environment conducive to promote terrorism swiftly, though there are factors that gain equal importance in counterbalancing the instigating factors. This study found out two main factors such as societal dogmas and extremist religious ideologies acting as factors pushing the youth into the morass of terrorism. The study also discovered two main factors such as people's 
persuasion and the State's coercion pulling the youth out of the quagmire of terrorism. Each would be discussed in the following pages in different sections.

\subsection{Push Factors: Societal Dogmas, Extremism, and Religious Ideologies}

\subsubsection{Societal Dogmas}

As a push factor, societal dogmas play their role. A dogma is set of principles followed as truth (Sharma, 2007). That is, a societal dogma is considered an inconvertible truth. In Pakistan's society, in this regard, certain dogmas are significant such as to be a better human being one has to be religious - in both appearance and action. This dogma offers a standard to every youth to follow as the first choice in the adulthood. The youth look for the company where the dogma is more prevalent (Koomen \& Pligt, 2016).

Anwar Ali, a young man hailing from Jhang, a city in southern Punjab, was an affiliate to the Sipah-e-Sahaba, a deadly sectarian organization, considered that it was the company of friends, backed by socio-physical religious sacrosanct surroundings, which drove him into the fold of the sectarian organization. Anwar Ali said:

"It is not the fault of the youth itself. It is because of the area in which you are born and your roam around. The circumstances make you go for a certain cause. Your company matters a lot" (personal communication, 2020).

The company of friends made him search for a cause in life. No doubt, the youth selected a company of friends which was considered pious and which carried religious credentials. Nevertheless, the same company got penetrated by the Jihad ideology. His point of view was endorsed by her mother, Tania Kulsoom, who had sought only primary education, blamed the company of friends of his son pushing his son into the life of terrorism. Anwar Ali's mother Tania Kulsoom, said:

"It is the company of the people that affect your thinking process. Good friends take you to a good path and bad friends take you to a bad path. In my son's case, his friends changed his mind ... Our society has become an evil society where no one is protected. When you send your children to school or college, you do not have an idea what type of friends they choose, what kind of people they meet, where they sit, and what type of company they have" (personal communication, 2020).

Asif Hussain, a young man from Sargodha, a city in central Punjab, was a member of the Jaishe Mohammad, a deadly Jihadist organization, active in both Afghanistan and Kashmir. He attributed his inclination to Jihad to the company of his friends. Asif Hussain said:

"The company of your friends matters a lot. If the guys with whom you spend most of your time are inclined to Jihad, then you will also do the same. There are rare chances of escape then.... The youth from areas like ours are often the victim of poverty and ignorance and they find no purpose in life. We, therefore, find our refuge in Jihad" (personal communication, 2020). 
Driven by poverty and ignorance, the youth look for a purpose in life (Koomen \& Pligt, 2016). The viewpoint of Asif Hussain was seconded by his father, Ghafoor Hussain, who was a peon in a government office, and attributed the deviation of his son to the social and religious beliefs which are driving the society. Asif Hussain's father, Ghafoor Hussain, who was peon in a government office, said:

"We all are born with social and religious beliefs. All our life, we are taught of these beliefs, which play an important role in our lives...It is society and the people's company with whom you spend most of your time decides your destiny" (personal communication, 2020).

The power of social and religious beliefs remains unchallenged (Sharma, 2007). Umar Muavia, a young man hailing from Jhang, a city in the southern Punjab, was an affiliate to the Lashkare Taibah, a deadly Jihadi organization functional in the area of Kashmir under the occupation of India. He also attributed his propensity for Jihad to the company of friends he followed. Umar Muavia said:

"Society is mainly responsible for making any one a social or religious person. In our society, a religious person is respected a lot than anyone else and this is a reason people tend to become religious...If you visit our area, from every second person you will hear the slogan that Jihad is the main purpose of life and that you are not the chosen one of Lord unless you join Jihad" (personal communication, 2020).

If an ideology that gets popular in an area of society, the youth inhabiting the area are bound to be influenced by the ideology. The view point of Umar Muavia was endorsed by his elder brother, Aslam Muavia, who was a motor mechanic. Aslam Muavia said:

"It is their own state of mind that takes them to a particular path. My brother since childhood was little more oriented towards religion than the rest of us, siblings... Family tries to keep a check but friends of a young man create a gathering where he learns either to be a social man or religious devotee" (personal communication, 2020).

The orientation of a child towards religion is considered valuable and convivial under the social belief or dogma that the child has a noble inclination in his life (Sharma, 2007). The child tries to seek the company that accentuates his much prized noble leaning. If an ideology pollutes that company which is a product of the misinterpretation of religion, members of the company are bound to be influenced by the ideology (Koomen \& Pligt, 2016).

\subsubsection{Extremist Religious Ideologies}

As a push factor, the extremist religious ideologies play their role. An extremist religious ideology is an ideology that promotes intolerance and narrows down the outlook of its follower (Koomen \& Pligt, 2016). After 1989, certain areas in Pakistan became hotbeds of extremist religious ideologies focused on launching Jihad either inside or outside the country. To some youth, such religious ideologies pander to their thrill for adventure and purpose in life. Religious teachings are brimming with the concept of pan-Islamism (Phillips, 2016; TajiFarouki \& Nafi, 2004). 
Anwar Ali was made to observe the sufferings of the Muslims all over the world. Instead of devising a formula or a mechanism to uplift the Muslims from their socio-economic miseries, he thought it apt to punish those whom he considered responsible for the plight of the Muslims. Anwar Ali said:

"Jihad is an important part of our religion. It is an obligation on each Muslim. As you see Muslim Ummah is suffering all over the world because of the men on whom Jihad is an obligation. Not going for Jihad is the real problem... Jihad is obligatory on every man and it is teaching of the Quran... Being a Muslim, it is obligatory for us to preach for Islam, we all preach in a peaceful way. It becomes violent only when the State takes the side of Kafirs and on the dictation of the USA kills our own people" (personal communication, 2020).

The youth carries credulous mind and they can be brainwashed to embrace new ideology, be it soft or lethal (Koomen \& Pligt, 2016). Anwar Ali's point of view was endorsed by her mother. Anwar Ali's mother Tania Kulsoom said:

"Agents of an organization act like religious devotees and destroy the lives of innocent ones...A good religious person become a pir, faqer, darvesh and saint while the rest become militants" (personal communication, 2020).

In these vulnerable areas, even parents engender a classification introducing good Muslims and bad Muslims. Nevertheless, teachers also play a role in promoting the concept of extremist religious ideologies. Asif Hussain said:

"In my case, a teacher of mine inspired me to take this path of Jihad. He had spent six years of his life in Afghanistan for conducting Jihad. He narrated to me some events of the suppressed state of the Muslims in the hands of foreign powers and told me the stories of Jihad attaining glorious victories. These stories inspired me to go for Jihad to play my role in transforming the lives of those whose responsibility lay on us" (personal communication, 2020).

One misguided person influences the path of another person. Jihad is adopted as a cause to transform the lives of others (Pilger, 2016). The underlying assumption remains firm that a Jihadist cannot change his own life but he can take it as a cause to improve the lives of other Muslims through the agency of Jihad, as religiously motivated youth are more prone to adopting this ideology (Koomen \& Pligt, 2016). Worthlessness of oneself and search for a cause to live life are the two main motivators (Phillips, 2016; Taji-Farouki \& Nafi, 2004).

Nevertheless, Asif Hussain's father, Ghafoor Hussain considered that though religion was necessary to live one's life, almost all religion promoting institutions in Sargodha were promoting the ideology of Jihad, thereby making an environment which was difficult for the youth to avoid. Asif Hussain's father, Ghafoor Hussain said:

"Our lives are directed by religion ... We are taught religion and we get trained by religion....My son was misguided on the context of Jihad ... In Sargodha, in almost all mosques, Jihad is glorified and that is why the youth decide to get that part of glory... Asif read the Quran with Tafseer and soon he developed the 
ideology of Jihad. One of his friends was in the Jaish-e Mohammad, so he started visiting his house frequently" (personal communication, 2020).

Nearness to mosques or frequent visits to mosques for learning and saying prayers was attributed to getting a moderate Muslim to turn into an extremist Muslim (Nesser,2018). One of the reasons given was that these places were frequented by members of extremist religious or Jihadist parties. This idea was backed by Umar Muavia who considered that, within the context of religion, finding a cause to live life was vital. Umar Muavia said:

"To become a devotee of the religion, you first have to owe your allegiance to the religion of Islam ... When you identify a cause of your life; you devote your life to achieve that goal ... The main purpose of an Islamic State is to expand boundaries of the Muslim Ummah, so to expand the boundaries, Jihad is must. Hazrat Umar ruled almost half of the world through Jihad and that was the glorious time of our history" (personal communication, 2020).

The youth visiting the mosques have been indoctrinated with the concept that an Islamic State cannot sit idle. The State has to expand its boundaries through the agency of Jihad and, if the State prevaricates on this duty, an individual Muslim can substitute the State and launch a personal level Jihad (Rogers, 2017; Taji-Farouki \& Nafi, 2004; Nesser, 2018). Nevertheless, Umar Muavia's elder brother considered that such an inclination to launch personal Jihad was contiguous dependent upon the locality one inhabited. Umar Muavia's elder brother Aslam Muavia said:

"Since we live in an area where every house has someone as a Jihadi, the ideology is much stronger to sway a youth" (personal communication, 2020).

In a favourable local environment, the concept of Jihad becomes viral thus affecting any youth of the society. Nevertheless, Qari Akram Hassan, who is a head of a Madrassa in Sargodha, exonerated Madrassas from disseminating the ideology of Jihad amongst the youth, though he admitted that devotees frequenting Madrassas were involved in promoting Jihad. Qari Akram Hassan said:

"People who use violence to express their religion are manipulated to do so. Some people adopt this path due to their circumstances and for being sick and tired of them...The madrassas have no role in promoting Jihad... Madrassas are for teaching Islamic principles and knowledge. However, some people associated with Madrassas do end up pushing the youth towards Jihad" (personal communication, 2020).

A Madrassa might not be teaching formally the ideology of Jihad and convincing the religious students to opt for the path of Jihad. A Madrassa does offer a meeting point for people to exchange their thoughts and get influenced by each other (Nesser, 2018). The ideology of Jihad may be one such shared thought.

Hitherto, in this section of the main discussion, the study showed that the societal dogmas and the extremist religious ideologies were the two main push factors to get the youth indulged in religious extremism. 


\subsection{Pull factors: Persuasion and State Coercion Bringing Youth back from the Brink}

\subsubsection{People's Persuasion}

As a pull factor, people's persuasion plays its role. The central institution in a society is family, which is still an intact body in Pakistan (Sharma, 2007). On the one hand, Anwar Ali was committed to joining the Jihadists while, on the other hand, her mother was pleading with him to abandon the Jihad project and get back to home. Anwar Ali said:

"My mother was against my going for Jihad and on her persuasion and her blackmailing, that she would commit suicide, motivated me to leave the path of Jihad...It was my family that persuaded me to refrain from Jihad. A Muslim is not afraid of the police and other law enforcement agencies, but as you know even Hajj is not acceptable if a devotee's mother does not permit him. In my case, I consulted Ulema and they said if your mother was not willing to let you go for Jihad, it would not be accepted" (personal communication, 2020).

Love with mother and with the family including siblings overwhelms a person to change one's mind (Sharma, 2007). In this way, Anwar Ali also changed his mind. His mother Tania Kulsoom said that he was not afraid of the police but loved his family and siblings, though the fear of the police harassing the family played a role in changing his mind. Anwar Ali's mother Tania Kulsoom said:

"When Adil ran away from house, he had stolen jewellery consisted of 4 gold rings and a gold chain, which were my lift time asset. When I came to know that he had joined the Sipah-e-Sahaba, I shuddered with the fear that the police would be after us. The police came to our house and the engagements of my two daughters broke. This was the time I beseeched him to either kill us or leave this path of Jihad. Thanks God, he listened to me and changed his mind" (personal communication, 2020).

Protection of the family remains a first concern of many, especially when the honour of the family is at stake by the police. Asif Hussain endorsed this point of view. Asif Hussain said:

"Mostly my family dissuaded me from adopting the path of Jihad. My family did that when it was threatened by the police, which used to pick up my father and brothers. I got demotivated when the Police threatened to arrest my sisters. I was in a hiding. My father called me and said that no one would marry your sisters if they spent a few seconds in the police station. I, therefore, came back and surrendered...In families like ours, visiting the police station is considered a matter of disgrace and this was the main reason for my abandoning Jihad" (personal communication, 2020).

For a common Pakistan, under any allegation, visiting a police station is a matter of disgrace and contempt, as it is perceived that the police do not invite nobility to the police station. The police try to pressurize the family to dissuade the misguided youth to surrender and return to normal life. Asif Hussain's father, Ghafoor Hussain said: 
"The family plays an important role in checking and curbing the tendency of violence and extremism in the youth" (personal communication, 2020).

The importance of a family to a deviant youth is also known to the police, which use the handle of family to influence the youth. It is an easier and direct way to solve such an issue in Pakistan. Umar Muavia said:

"I was in a hiding. My elder brother was arrested by the police. The police said that they would not let him go until I surrender for arrest. My elder brother suffered a heart attack in police custody. I, therefore, gave up" (personal communication, 2020).

In Pakistan, the police work on the family to produce an alleged and this system works in most cases. Family ties play their role in directing the family member to listen to the police. Umar Muavia's elder brother Aslam Muavia said:

"When Umar Muavia joined the Lashkar-e Taibah, the police arrested me. I suffered a heart attack in the police custody. The police said that they would not let me go even if I died until Umar Muavia surrendered to them. They also threatened that they would arrest other family members. This situation pushed the family to advise Umar Muavia to surrender and he did it" (personal communication, 2020).

The institution of family has made possible the recovery of misguided delinquent youth from the clutches of religious extremism including terrorism and Jihadism. The role of the family as an institution is also recognized by heads of Madrassas and they consider that the institution of family is still strong enough sending a Jihadi back to normal life. Qari Abdullah Bandialvi, head of a Madrasah said:

"There are two types of Jihadis. Some died there in the battlefield in Afghanistan. Some got tired and came back and some came back by listening to their parents, family members and friends" (personal communication, 2020).

Interestingly, extremist religious organizations do not engage the youth by persuading families to devote their children to their cause but they see reversion of the Jihadis to normal moderate religious life under the persuasion of the institution of family.

\subsubsection{State's Coercion}

As a pull factor, the State's coercion plays its role. Whereas family is an informal institution of society, the State (and its departments) is a formal institution of society (Phillips, 2016). In Pakistan, though the institution of family is stronger than the institution of the State, the latter still has a role to play. Anwar Ali said:

"The main problem with our State is that its officials do not check a problem when it is at its nascent stage, where most of us cannot decide between right and wrong. We [the youth] therefore, fell victim to the negativity. When we do not have a path to come out of it then the State and all its agencies become active" (personal communication, 2020). 
The State becomes active after the event: The State does not use pre-emptive measures to halt the situation from falling into a crisis. Anwar Ali's mother Tania Kulsoom said:

"The police kept on knocking at our door repeatedly and harassed us. They used to come and sit outside our house. We had no choice but to leave our house and shift elsewhere...Anwar was not fearful of the police. He changed his mind on my persuasion" (personal communication, 2020).

The intelligence agencies of the State play no role in reading the deteriorating situation, as the contagious nature of the ideology of Jihad is not unknown (Phillips, 2016). The police get active after an event instead of precluding it (Cohen, 2016). Asif Hussain said:

"There is no enforcement of law or the threat of the State when you are preparing for Jihad...I think it is persuasion by society and the social circle to drop the ideology of Jihadism and get back to normalcy" (personal communication, 2020).

Asif Hussain's father, Ghafoor Hussain said:

"The punishments do deter the evils from society but the problem is that the State comes late after the things get out of hand" (personal communication, 2020).

The State's departments dealing with counter-terrorism spur into action when the situation goes out of control (Cohen, 2016). These departments remain behind time in dealing with the situation. Umar Muavia thinks that this is why the police have to rely on indirect methods such as coercing the family instead of direct methods such as catching the culprit and his accomplices. Umar Muavia said:

"The State's coercive hand is not any deterrence. Instead, the fear that the police would arrest family members is dissuasion. This fear dissuades the youth from going ahead with Jihadism" (personal communication, 2020).

Umar Muavia's elder brother Aslam Muavia said:

"The behavior of the police with families play an important role in forcing the youth stay away from extremism and terrorism... The way the police humiliates, one cannot dare go against the interests of the State" (personal communication, 2020).

The police have got hold of the handle of dealing with the tendency of extremism in the youth by coercing the family and this is why the State agencies remain lax until the crisis point reaches. Qari Nafeh Mustafa thinks that it is so because the police are trained to remain vigilant on criminal activities happening daily instead of terrorist activities occurring infrequently. Qari Nafeh Mustafa, head of a Madrassa said:

"The primary role of the State's law enforcing agencies is to minimize the crime rate in society. There are some people who misinterpret religion to engage in 
bloodshed which is crime in the eyes of the law. Such criminals are controlled using the State's law enforcing agencies" (personal communication, 2020).

The weakness of the police to remain focused on dealing with the crime rate is affecting their performance on daily basis. Nonetheless, it is known to the religious circles engaged somehow in activities bordering on terrorism abhorred by society (Cohen, 2016). This might be one of the reasons for religious extremism to flourish in the society. The perpetrators remain below the threshold where they remain unnoticed unless a terrorism-related crisis appears that instigates the police into action. If any coercion applies by the State is present, it begins after a terrorist event.

Hitherto, in this section, the study showed that people's persuasion and the State's coercion were the two main pull factors to retrieve the youth from religious extremism. These factors acted as a counterbalancing force to bring the youth back to normal life of a moderate Muslim in the society.

\section{Conclusion and Recommendations}

\subsection{Conclusion}

The study examined contribution of societal dogmas and extremist religious ideologies to pushing the youth to religious extremism and contribution of people's persuasion and the State's coercive measures ranging from law enforcement to physical actions to pull the youth return to peace and ultimately lead a better lifestyle while creating a safer country and environment. The study elicited four main findings. First, societal dogmas to devote one's life for a religious cause worked as a factor motivating the youth to resort to extremism. Second, extremist religious ideologies centred upon Jihadism to sacrifice one's life for a religious cause motivated the youth to terrorism. It is evident from the interviews of reformed extremists that religion played a huge role in promoting an extremist mindset, with the promise of Heaven an even larger motivator for some. Third, people's persuasion especially persuasion by siblings and parents acted as a major pull factor to bringing the youth back to normal life. Despite having suffered greatly in following extremist ideologies, it is family that brings these people back from the edge. Fourth, the State's coercive hand such as enforcement of law and order, jails and police actions dissuaded the youth to tread further the path of terrorism. The states rehabilitation efforts are not going to waste and showed results with the number of former extremists that they have rehabilitated. In short, though the pull factors such as societal dogmas and religious ideologies played their role in motivating the youth to terrorism, the pull factors such as people's persuasion and the State's coercion outclassed them to assert peace which recycled itself to dissuade the youth from falling into the abyss of terrorism.

\subsection{Recommendations}

There is a dire need for enhancing the intelligence surveillance of areas knows as hotbeds for fomenting religious or sectarian hatred amongst the youth. These areas are well known and should have a dedicated force in cohorts with the leaders of the areas to ensure that people do not stray from the path set for them. Moreover, the institution of family should be strengthened to enhance its inherent persuasion power on the family members. This institution provides valuable aid to the police in terms of coercing or persuading the families and should be protected from weakening as a matter of importance. 
The youth is in desperate need of finding a purpose in life. The State should play an active role in offering the youth a productive purpose in life before the youth become deviant and sets eyes on any destructive purpose in life. For this purpose, vocational training institutes need to be opened in vulnerable areas such as Jhang and Sargodha engaging the youth in constructive activities that could help them be busy and be financially stable. The youth should be made active to find the purpose of life in healthy social and sports activities than in deadly activities such as religious extremism and Jihad. Sports stadiums be constructed to let the youth give vent to their competitive urges and energies. There should be incentives for the youth to utilize their talents and skills elsewhere and keep themselves busy so that they do not fall under the wrong influences and develop an extremist mindset.

A program of continuous dissemination of a narrative demotivating youth from the ideology of Jihad is required. The program needs to focus on both mosques and Madrassas to keep checking and forestalling the ideology of religious extremism. Furthermore, religious leaders need to be taken on board to ensure that the ideologies preached have authority behind them and hence can influence a greater number of people. Lastly, all preaching material promoting the tendency of pan-Islamism should be checked and the State should employ pre-emptive measures to forestall the tendency to religious extremism.

\section{References}

Ahmed, K. (2012). Sectarian War: Pakistan's Sunni-Shia Violence and its Links to the Middle East. Oxford University.

Aslam, T. \& Aslam, M. A. (2020). FATF's Concerns and Pakistan's Measures for Compliance. Liberal Arts and Social Sciences International Journal (LASSIJ), 3(2), 184-195. https://doi.org/10.47264/idea.lassij/3.2.20

Chebotareva, E. (2014). Psychological Factors of Ethnic Extremism in Muslim youth. Mediterranean Journal of Social Sciences, 5(22), 140-148. https://doi.org/10.5901/mjss.2014.v5n22p140

Cohen, S. P. (2016). The South Asia Papers: A Critical Anthology of Writings. Brookings Institution.

Doosje, B., Loseman, A., \& Van Den Bos, K. (2013). Determinants of Radicalization of Islamic Youth in the Netherlands: Personal Uncertainty, Perceived Injustice, and Perceived Group Threat. Journal of Social Issues, 69(3), 586-604. https://doi.org/10.1111/josi.12030

Haqqani, H. (2013). Magnificent Delusions Pakistan, the United States, and an Epic History of Misunderstanding. Public Affairs.

Ismail, M., Shah, A. A., Saleem, K., \& Khan, A. (2020). Why Educated Youth Inclined Toward Extremism: A Case of Higher Education Institutes of Pakistan. Asian Journal of Comparative Politics. https://doi.org/10.1177/2057891120926567

Khan, H. A. (2018, April 4). 139 Terrorists Connected to Pakistan on Un Sanctions List. The Express Tribune. https://tribune.com.pk/story/1677131/139-terrorists-connectedpakistan-un-sanctions-list

Khan, S., Wazir, T. \& Khan, A. (2019). The Effects of Militancy and Military Operations on Pashtun Culture and Religion in FATA. Liberal Arts and Social Sciences International Journal (LASSIJ), $\quad 3(1), \quad 73-82$. https://doi.org/10.47264/idea.lassij/3.1.7 
Khan, Z., Ullah, R., \& Kamal, U. (2020). Pathways of Youth Radicalization in Pashtun Society: Applying the Anomie and Strain Theory. Liberal Arts and Social Sciences International Journal (LASSIJ), $\quad 3(2), \quad 150-158$. https://doi.org/10.47264/idea.lassij/3.2.17

Koomen, W., \& Pligt, J. V. D. (2016). The Psychology of Radicalization and Terrorism. Routledge, Taylor \& Francis Group.

MacDonald, M. (2017). Defeat is an Orphan: How Pakistan Lost the Great South Asian War. C. Hurst.

Nesser, P. (2018). Islamist Terrorism in Europe. Hurst \& Company.

Phillips, C. (2016). The Battle for Syria: International Rivalry in the New Middle East. Yale University.

Pilger, J. (2016). The New Rulers of the World. Verso Books

Rogers, P. (2016). Irregular War: Isis and the New Threat from the Margins. I. B. Tauris.

Sharma, R. K. (2007). Fundamentals of Sociology. Atlantic Publishing.

Taji-Farouki, S., \& Nafi, B. M. (2004). Islamic Thought in the Twentieth Century. I. B. Tauris.

United Nations Security Council. (2019, May 1). Mohammed Masood Azhar Alvi. United Nations. $\quad$ https://www.un.org/securitycouncil/content/mohammad-masood-azhar$\underline{\text { alvi }}$

Wasai, Ullah, J., \& Bano, A. (2020). Militancy and Pashtun Culture: Challenges and Developments in Pashtun Society in Khyber Pakhtunkhwa, Pakistan. Liberal Arts and Social Sciences International Journal (LASSIJ), 3(2), 115-127. https://doi.org/10.47264/idea.lassij/3.2.14

Woodward, B. (2011). Obama's Wars. Simon \& Schuster.

Yousaf, K. (2019, February 21). JuD, FIF Charities Banned as Govt Seeks to Rout Extremism. The Express Tribune. https://tribune.com.pk/story/1915620/pakistanbans-hafiz-saeeds-charities-hints-action-group-blamed-pulwama-attack

Yusof, N., Kaur, A., Sani, M., \& Hashim, R. (2019). A Qualitative Expert Interview Approach Towards Understanding Religious Extremism among Malaysian Youth. The Qualitative Report,24(7), 1577-1592. https://doi.org/10.46743/2160$\underline{3715 / 2019.3624}$ 